\title{
ШКОЛСКИ DЕLF У СРБИЈИ: РЕЗУЛТАТИ НА ИСПИТИМА И НАЧИН РАДА У ШКОЛИ
}

\section{Сажетак}

Испити из француског језика за стицање диплома Министарства просвете Француске DELF/DALF организују се у Србији од 1994. године. Године 2007. прве школе отварају врата програму школски DELF (DELF scolaire) са нивоима A1-Б2 организованом у школским установама за ученике виших разреда основне школе и средње школе.

Аутор даје кратак преглед увођења испита DELF у Србији за ученике у школским установама, као и резултате постигнуте на испитима. Квантитативној анализи аутор додаје и анализу видљивих, могућих и очекиваних узрочно-последичних односа процеса подучавања/ учења с једне, и полагања испита DELF с друге стране. Отварају се и два важна питања. Прво је питање реалних могућности и ефикасности начина рада у процесу подучавања/ учења у условима карактеристичним за школске установе у Србији: да ли ова врста екстерне евалуације комуникативне компетенције ученика даје увид у резултате рада на редовним часовима. Друго је питање да ли и како похађање DELF семинара и припремање ученика за полагање испита утиче на промену метода рада професора (приоритети, одабир приступа у процесу подучавања/ учења, аутономизација ученика, евалуација итд).

Кључне речи: основне школе, DELF испити, настава француског језика у формалном образовању.

\section{Увод}

У Србији (без Косова и Метохије) у току 2014-2015. школске године било је 1128 матичних основних школа (са издвојеним одељењима преко 3350) са 555573 ученика. Француски језик се учио у 34 шко-

* adosenovic@mts.rs 
ле као први страни језик (близу 10000 ученика) и у 385 школа као други страни језик (близу 81000 ученика). ${ }^{1}$

Последњих година примећен је пад интересовања за француски језик код ученика четвртог разреда основне школе који треба да изаберу други страни језик који ће учити од петог разреда. По свему судећи, у највећем броју случајева у питању је заправо пад интересовања код родитеља тих ученика јер они су ти који махом одлучују о избору страног језика. Нећемо улазити у анализу узрока ове појаве, али ћемо касније размотрити позитиван утицај који испити из програма школски DELF могу имати и имају како на учење француског језика у основним школама, тако и на мотивацију најмлађих ученика и њихових родитеља.

\section{Заступљеност програма школски DELF у Србији}

Испити из француског језика за стицање диплома Министарства просвете Републике Француске DELF/DALF постоје од 1985. године, намењени су кандидатима свих узраста и обухватају све нивое знања, од почетног до највишег. ${ }^{2}$ У данашњем облику, са четири нивоа за DELF (A1, A2, Б1 и Б2) и два нивоа за DALF (Ц1 и Ц2) усклађеним са нивоима Заједничког европског оквира за живе језике Савета Европе објављеним први пут на енглеском језику 2001. године (у даљем тексту ЗЕРОЈ), постоје од 2005. године, а у међувремену је уведен и ниво A1.1 за децу до 12 година. Испити се одржавају у више од 1000 центара у 164 земље света. Постоји пет верзија DELF испита и једна верзија DALF испита и то:

DELF Prim (A1.1, A1 и A2) за децу од седам до 12 година;

DELF junior и DELF scolaire (A1, A2, Б1 и Б2) за децу и младе од 12 до 17 година;

1 По подацима Републичког завода за статистику за школску 2014-2015. годину. У тренутку писања овог текста, подаци за школску 2015-2016. годину још нису били обрађени.

2 Сви подаци о испитима DELF/ DALF у овом раду преузети су од Међународног центра за педагошке студије (CIEP - Centre international d'études pédagogiques), установе задужене за испите DELF/ DALF, односно од Француског института у Србији за све што се тиче Републике Србије. 
DELF tout public (A1-Б2) за одрасле;

DELF Pro (A1-Б2) за језик струке;

DALF (Ц1 и Ц2) за одрасле.

Верзије DELF junior и DELF scolaire (у даљем тексту школски DELF) намењене су кандидатима исте старосне доби, обе имају нивое A1, A2, Б1 и Б2 и тематски су прилагођене интересовањима деце и младих тог узраста. Једина разлика између ове две верзије је што је испит школски DELF институционализован, могу га полагати само ученици који похађају школе које су у мрежи школски DELF, док је DELF junior отворен за све младе тог узраста, без обзира коју школу похађају. За успостављање мреже школски DELF у било којој земљи, потребно је да министарство просвете те земље потпише са амбасадом Француске споразум о сарадњи и утврди тачан списак школа које улазе у програм. Тај списак није коначан ни затворен, будући да се број школа може из године у годину повећавати или смањивати.

Све дипломе, без обзира на верзију и публику, усклађене су са одговарајућим нивоом ЗЕРОЈ, независне су једна од друге, имају неограничен рок трајања и међународно су признате. Сваки кандидат само једном може да добије диплому одређеног нивоа, без обзира на старосну доб. Тако, на пример, кандидат који је стекао диплому DELF Prim A2 до своје дванаесте године, неће поново полагати тај ниво као одрасла особа будући да диплому нивоа А2 већ поседује. Сви испити састоје се из 4 дела који одговарају основним језичким вештинама, и то рецептивним: разумевање говора и разумевање писаног текста, и продуктивним: писање и говор.

За полагање испита није потребан никакав предуслов сем да кандидат припада старосној доби предвиђеној за одређену верзију испита. Испити су независни један од другог што значи да кандидат нивоа A2, на пример, не мора имати диплому нивоа А1. Испите могу полагати сви, без обзира где и како су учили језик, са професором или самостално, у школама у систему, у школама страних језика или на било ком другом месту, у земљи у којој полажу испите или у иностранству. Изузетно, за школски DELF кандидати морају бити ученици школа које су у мрежи школски DELF у школској години у току које полажу испит. 
Испити DELF/DALF у Србији се организују од 1994. године, у почетку само у две верзије, DELF junior и DELF tout public. Од 2005. године испити се полажу у данашњој форми, са 6 нивоа усклађених са нивоима ЗЕРОЈ. Године 2007, прве школе отварају врата програму школски DELF организованом у школским установама за ученике виших разреда основне школе и средње школе, да би потом 2009. године био потписан и званичан споразум између Министарства просвете, науке и технолошког развоја Републике Србије и Француске амбасаде у Србији. Старосна граница од 17 година за младе дефинисана је у нашој земљи на нешто другачији начин, тачније до краја циклуса средњег образовања и васпитања. Најзад, 2011. године, уводи се и четврта верзија, DELF Prim. Од 2005. године укупно су издате 9462 дипломе (в. Табелу 1).

Табела 1. Број издатих диплома DELF/DALF по нивоима од 2005. до септембра 2016.

\begin{tabular}{|c|c|c|c|c|c|c|}
\hline A1.1 & A1 & A2 & Б1 & Б2 & Ц1 & Ц2 \\
\hline 145 & 3527 & 3045 & 1716 & 844 & 170 & 15 \\
\hline
\end{tabular}

Сви испити се плаћају у износу који утврђује Француски институт у Србији (в. Табелу 2 за цене испита у току школске 2015-2016. године).

Табела 2. Цене испита за школску 2015-2016. годину изражене у динарима.

\begin{tabular}{|l|c|c|c|c|c|c|c|}
\hline & $\mathrm{A} 1.1$ & $\mathrm{~A} 1$ & $\mathrm{~A} 2$ & $\mathrm{5} 1$ & Б2 & Ц1 & Ц2 \\
\hline DELF Prim & 6000 & 6000 & 6000 & $\mathrm{x}$ & $\mathrm{x}$ & $\mathrm{x}$ & $\mathrm{x}$ \\
\hline DELF tout public & $\mathrm{x}$ & 5000 & 5000 & 7000 & 9000 & 11000 & 13000 \\
\hline DELF junior & $\mathrm{x}$ & 5000 & 5000 & 7000 & 9000 & $\mathrm{x}$ & $\mathrm{x}$ \\
\hline DELF scolaire & $\mathrm{x}$ & 2500 & 2500 & 3500 & 4500 & $\mathrm{x}$ & $\mathrm{x}$ \\
\hline
\end{tabular}

Како се из приложене табеле види, цене за испите школски DELF ниже су за 50\% од цена за исте нивое верзија DELF junior и DELF tout public. Ова одлука донета је у жељи да у погледу финансија полагање испита буде приступачно што већем броју ученика. Тако су ученици који полажу школски DELF на два начина привилеговани у односу на остале кандидате. С једне стране, цена испита за њих је 
знатно нижа, а с друге, они испит полажу у свом граду или у његовој непосредној близини те немају трошкове превоза ни за себе ни за пратиоце/ родитеље, или су трошкови сведени на минимум.

Испити школски DELF одржавали су се у Србији два пута годишње, на пролеће и на јесен, у 2007. и 2008. години, 2009. нису одржани из техничких разлога, а од 2010. године одржавају се једном годишње, на пролеће. Програм школски DELF развија се у Србији крупним корацима. Од тек неколико школа у првој години, данас их има чак 100 међу којима 61 основна школа (од укупно 419 основних школа у којима се учи француски језик) и 39 гимназија и средњих стручних школа.

Увођење програма школски DELF, можемо слободно рећи, знатно је изменило слику учења француског језика у Србији, како у квантитативном и географском смислу, тако и квалитативно. Кандидати нису више само „привилеговани“ који живе у градовима испитним центрима (Београд, Ниш, Нови Сад и Кладово) или у њиховој близини, који имају прилике да уче француски језик у некој школи страних језика или да имају приватне часове са професором који је упућен у систем испита или је и сам испитивач DELF/DALF.

\section{Обучавање испитивача}

Да би се добило звање испитивача DELF/DALF потребно је завршити обуку и положити за сваки ниво посебно тест који се састоји у оцењивању говора или писања једног кандидата датог нивоа уз детаљна образложења оцена. Лиценца се добија по нивоима по реду, дакле, да би се добила за ниво Б1, на пример, потребно је имати лиценцу за нивое A1 и А2. Лиценца важи пет година од датума издавања и потом се обнавља опет полагањем теста. Програм обуке и испитни материјал обезбеђује CIEP, а обуку реализују лиценцирани инструктори испитивача. Поред доброг нивоа језика, критеријуми за додељивање лиценце су и: редовно присуствовање семинарима; рад и пертинентност размишљања, коментара и питања на семинарима; познавање карактеристика датог нивоа по ЗЕРОJ; познавање и примењивање принципа позитивне критеријумске евалуације; давање 
оцена у предвиђеном распону и детаљна и пертинентна образложења оцена.

У Србији се обука нових испитивача врши редовно сваке јесени, док се обнављање лиценце обавља на пролеће. За прво стицање лиценце организује се такозвани хибридни модел обуке: два дана обуке in situ посвећена евалуацији уопште, ЗЕРОЈ, основним принципима испита DELF/DALF и карактеристикама нивоа A1 и A2. Следи самосталан рад од пет недеља уз помоћ инструктора ментора који се завршава још једним семинаром in situ да би се заокружио рад и полагао тест. Истог дана уводе се нивои Б, следи пет недеља самосталног рада и још један семинар in situ када се полаже и тест Б. Веома мали број искусних испитивача (тренутно их има само 10) обучава се за нивое Ц по истом принципу. Ова шема $2+5+1+5+1$ са алтернирањем рада на семинарима in situ и самосталног рада уз помоћ ментора омогућава професорима да се подробније упознају са ЗЕРОЈ и принципима позитивне евалуације, да размишљају, постављају питања, дискутују између себе и са инструкторима. Прва два дана обуке намењена су не само професорима који желе да постану испитивачи, већ свима који желе да припремају своје ученике за полагање испита DELF/DALF, без обзира где раде.

Програм DELF/DALF у Србији окупља у овом тренутку 166 лиценцираних испитивача за нивое А, од којих 101 и за нивое Б и 10 и за нивое Ц. ${ }^{3}$ Њих 70 (дакле нешто више од 42\%) ради у 61 основној школи у систему школски DELF.

\section{Резултати остварени на испитима}

Током 10 година постојања система школски DELF у Србији издате су укупно 3702 дипломе, за ученике основних и средњих школа. Највише кандидата положило је, наравно, ниво А1, нешто мало мање ниво А2, затим око три пута мање ниво Б1 и најзад чак 20 пута мање ниво Б2 (Табела 3).

3 У школама у систему у Србији ради укупно око 1100 професора француског језика. Тачан број је тешко установити јер се стално мења, а осим тога неки професори раде истовремено у две, па чак и три школе. 
Табела 3. Број издатих диплома у систему школски DELF по нивоима од 2007. до 2016.

\begin{tabular}{|c|c|c|c|}
\hline A1 & A2 & Б1 & Б2 \\
\hline 1745 & 1328 & 549 & 80 \\
\hline
\end{tabular}

Слика се значајно мења ако се задржимо само на основним школама што ће нам показати подаци у даљем тексту. Нажалост, није било могуће урадити анализу по разредима јер је у бази података уписано само годиште кандидата тако да смо у оквиру истраживања морали да обрађујемо податке о ученицима од 11 до 14 година за сваку календарску годину што углавном одговара ученицима појединих разреда, али што исто тако доприноси извесним непрецизностима због одређеног броја ученика који су пошли у школу раније или евентуално чак касније. Не треба заборавити ни чињеницу да велики број кандидата долази из основне школе „Владислав Рибникар“ из Београда у којој се француски језик учи по посебном програму од првог до осмог разреда са шест часова недељно. То је још један фактор који утиче на број кандидата по нивоу и на средњу оцену, али није било могуће издвојити ученике те школе јер у бази података није наведена школа коју ученик похађа већ само његово име и презиме (као заштићен податак).

У Табели 4 навели смо податке о броју кандидата од 11 до 14 година по години полагања испита и по нивоу, с процентом пролазности и средњом оценом кандидата који су положили испит. 
Табела 4. Обједињени статистички подаци о броју кандидата узраста 11-14 година, по години полагања испита и по нивоу са процентом пролазности и просечном оценом кандидата који су положили испит.

\begin{tabular}{|c|c|c|c|c|c|}
\hline Година & Ниво & $\begin{array}{l}\text { Изашли } \\
\text { на испит }\end{array}$ & $\begin{array}{c}\text { Положили } \\
\text { испит }\end{array}$ & $\begin{array}{c}\text { Проценат } \\
\text { пролазности }\end{array}$ & $\begin{array}{l}\text { Просечна оцена (од } \\
100) \text { кандидата који } \\
\text { су положили испит }\end{array}$ \\
\hline \multirow{5}{*}{2007.} & A1 & 58 & 58 & $100 \%$ & 88,17 \\
\hline & A2 & 84 & 80 & $95,23 \%$ & 77,13 \\
\hline & Б1 & 45 & 37 & $82,22 \%$ & 67,72 \\
\hline & Б2 & 5 & 1 & $20 \%$ & 53 \\
\hline & Укупно & 134 & 118 & $74,36 \%$ & 71,50 \\
\hline \multirow{5}{*}{2008.} & A1 & 32 & 32 & $100 \%$ & 82,28 \\
\hline & $\mathrm{A} 2$ & 26 & 23 & $88,46 \%$ & 74,39 \\
\hline & Б1 & 25 & 23 & $92 \%$ & 66,46 \\
\hline & Б2 & 1 & 0 & $0 \%$ & 1 \\
\hline & Укупно & 84 & 78 & $70,11 \%$ & 74,38 \\
\hline \multirow{5}{*}{2010.} & A1 & 17 & 17 & $100 \%$ & 84,09 \\
\hline & A2 & 10 & 10 & $100 \%$ & 73,80 \\
\hline & Б1 & 2 & 0 & $0 \%$ & 1 \\
\hline & Б2 & 0 & 1 & 1 & 1 \\
\hline & Укупно & 29 & 29 & $66,67 \%$ & 78,94 \\
\hline \multirow{5}{*}{2011.} & A1 & 117 & 116 & $99,14 \%$ & 73,42 \\
\hline & A2 & 16 & 10 & $62,50 \%$ & 83,35 \\
\hline & Б1 & 16 & 16 & $100 \%$ & 69,41 \\
\hline & Б2 & 0 & 1 & 1 & 1 \\
\hline & Укупно & 149 & 142 & $87,21 \%$ & 75,39 \\
\hline \multirow{5}{*}{2012.} & A1 & 121 & 118 & $97,52 \%$ & 75,83 \\
\hline & A2 & 43 & 41 & $95,34 \%$ & 74,57 \\
\hline & Б1 & 6 & 6 & $100 \%$ & 76,08 \\
\hline & Б2 & 0 & 1 & 1 & 1 \\
\hline & Укупно & 170 & 165 & $97,62 \%$ & 75,49 \\
\hline \multirow{5}{*}{2013.} & A1 & 201 & 195 & $97,01 \%$ & 76,66 \\
\hline & A2 & 47 & 47 & $100 \%$ & 77,99 \\
\hline & Б1 & 4 & 4 & $100 \%$ & 69,25 \\
\hline & Б2 & 1 & 1 & $100 \%$ & 84,50 \\
\hline & Укупно & 253 & 247 & $99,25 \%$ & 77,10 \\
\hline
\end{tabular}




\begin{tabular}{|c|c|c|c|c|c|}
\hline \multirow{5}{*}{2014.} & A1 & 336 & 325 & $96,72 \%$ & 77,76 \\
\hline & A2 & 68 & 67 & $98,52 \%$ & 79,81 \\
\hline & Б1 & 7 & 5 & $71,42 \%$ & 67,50 \\
\hline & Б2 & 0 & 1 & 1 & 1 \\
\hline & Укупно & 411 & 397 & $88,89 \%$ & 75,02 \\
\hline \multirow{5}{*}{2015.} & A1 & 204 & 203 & $99,51 \%$ & 74,83 \\
\hline & A2 & 63 & 62 & $98,41 \%$ & 73,02 \\
\hline & Б1 & 11 & 11 & $100 \%$ & 69,95 \\
\hline & Б2 & 0 & 1 & / & I \\
\hline & Укупно & 278 & 276 & $99,31 \%$ & 72,60 \\
\hline \multirow{5}{*}{2016.} & A1 & 147 & 142 & $96,59 \%$ & 75,01 \\
\hline & A2 & 52 & 49 & $94,23 \%$ & 79,90 \\
\hline & Б1 & 3 & 3 & $100 \%$ & 71,33 \\
\hline & Б2 & 0 & 1 & 1 & 1 \\
\hline & Укупно & 202 & 194 & $96,94 \%$ & 75,41 \\
\hline \multirow{5}{*}{$\begin{array}{l}2007- \\
2016 .\end{array}$} & $\begin{array}{l}\text { Укупно } \\
\text { A1 }\end{array}$ & 1.233 & 1.206 & $97,81 \%$ & 78,74 \\
\hline & $\begin{array}{l}\text { Укупно } \\
\text { А2 }\end{array}$ & 409 & 389 & $95,11 \%$ & 77,10 \\
\hline & Укупно Б1 & 119 & 105 & $88,23 \%$ & 69,51 \\
\hline & Укупно Б2 & 7 & 2 & $28,57 \%$ & 68,75 \\
\hline & \begin{tabular}{|l} 
Укупно \\
сви нивои
\end{tabular} & 1768 & 1702 & $77,43 \%$ & 73,52 \\
\hline
\end{tabular}

Не улазећи у подробну анализу свих података у табели, скренућемо пажњу само на неколико детаља. Уочљив је нагли пораст броја кандидата на свим нивоима, а нарочито на нивоу A1, од 2011. године што се подудара са уласком великог броја школа у систем у току школске 2010-2011. године, након званичног потписивања споразума. Проценат пролазности углавном је стабилан, изнад $96 \%$ за ниво А1, изнад $88 \%$ за А2 и изнад $82 \%$ за Б1, сем када је испит полагало мало кандидата, а неколико њих или нико није успео да положи. На пример, у 2010. години било је два кандидата за Б1 и ниједан није успео да положи испит, дакле пролазност је $0 \%$ или у 2011. од 16 кандидата А2 само 10 је положило испит па је пролазност била тек $62,50 \%$. За ниво Б2 укупно је било седам кандидата од којих су само два положила испит тако да је проценат пролазности врло низак, само 28,57\%. То није изненађујуће с обзиром на узраст ученика основне школе и програм по којем се ради. 
Просечна оцена најбоља је за ниво A1 $(78,74 / 100)$ и незнатно слабија за ниво А2 (77,10/100). Просечна оцена за ниво Б1 $(69,51 / 100)$ показује у највећем броју случајева резултат рада ученика основне школе „Владислав Рибникар“ који у осмом разреду достижу овај ниво, док би оцену за Б2 са укупно два кандидата за 10 година требало изузети из разматрања у овом контексту.

Занимљиво је погледати однос оцена појединих делова испита. Наиме, сви DELF испити састоје се из четири дела и то: разумевање говора, разумевање писаног текста, писање и говор. Сваки део има по 25 бодова што у збиру даје 100 бодова од чега је за добијање дипломе потребно најмање 50. Исто тако, за сваку од четири језичке вештине потребно је имати најмање пет бодова, без обзира на крајњи збир. Табела 5 приказује просечну оцену за поједине делове испита по нивоима (А1-Б1).

Табела 5. Просечна оцена по нивоу за сваку језичку вештину за узраст 11-14 година.

\begin{tabular}{|c|c|c|c|c|c|c|}
\hline Ниво & $\begin{array}{c}\text { Број } \\
\text { издатих } \\
\text { диплома }\end{array}$ & $\begin{array}{c}\text { Разумевање } \\
\text { говора } \\
\text { (од 25) }\end{array}$ & $\begin{array}{c}\text { Разумевање } \\
\text { писаног текста } \\
\text { (од 25) }\end{array}$ & $\begin{array}{c}\text { Писање } \\
\text { (од 25) }\end{array}$ & $\begin{array}{c}\text { Говор } \\
\text { (од 25) }\end{array}$ & $\begin{array}{c}\text { Укупно } \\
\text { (од 100) }\end{array}$ \\
\hline A1 & 1206 & 18,43 & 19,66 & 20,18 & 20,46 & 78,74 \\
\hline A2 & 389 & 18,14 & 19,95 & 18,28 & 20,71 & 77,10 \\
\hline Б1 & 105 & 16,40 & 17,71 & 15,56 & 19,83 & 69,51 \\
\hline
\end{tabular}

Обично се сматра да је у условима школског учења језика лакше развијати рецептивне вештине, нарочито разумевање писаног текста, док развијање продуктивних вештина захтева много времена, између осталог и због великог броја ученика у једном одељењу. У том смислу је донекле неочекивано да су код деце узраста 11-14 година која су положила испите у програму школски DELF, просечне оцене за ниво A1 за вештине продукције (писање и говор) мало изнад просечних оцена за вештине рецепције (разумевање говора и разумевање писаног текста). За нивое А2 и Б1, најбоље резултате кандидати су показали за вештину говора након чега следи разумевање писаног текста. Највећа разлика у просечним оценама између појединих делова испита појављује се на нивоу Б1 где је просечна оцена за писање знатно 
нижа од просечне оцене за говор (15,56/25 у односу на 19,83/25). Код нивоа A1 и А2 распон у којем се крећу просечне оцене је релативно мали $(18,43 / 25$ и $20,46 / 25$ за A1, односно $18,14 / 25$ и 20,71/25 за A2).

\section{Школски DELF као нека врста екстерне евалуације резултата рада?}

Број ученика у основним школама у систему школски DELF који полажу испите и њихови резултати заиста су више него задовољавајући. Професори који им предају прошли су обуку за испитиваче DELF, бар један у свакој школи, и несумњиво доприносе популаризацији DELF испита и порасту броја кандидата у програму школски DELF.

Поставља се, међутим, питање у којој мери су резултати на испитима показатељи знања и вештина стечених током редовног рада на часовима. Може ли професор у нашим условима рада да организује и реализује наставу тако да ученици постигну овако добре резултате са само два часа недељно?

Да бисмо стекли неку слику о томе, спровели смо анкету за професоре испитиваче запослене у основним школама у систему школски DELF. Анкету смо послали путем мејла, а они су нам је потом вратили попуњену, такође путем мејла. Од 70 професора, 42 су учествовала у анкети, дакле тачно 60\%, што је добра полазна тачка за анализу. Један од професора ради у две школе, у једној предаје француски као први страни језик, а у другој као други страни језик, те је попунио анкету два пута, за сваку школу посебно. Међу анкетираним професорима четворо раде у основној школи „Владислав Рибникар“ те ћемо, тамо где буде потребно, скренути пажњу на специфичност рада у тој школи. Будући да је верзија испита школски DELF предвиђена за ученике виших разреда основне школе, питања у анкети ограничили смо на ту старосну доб.

Од 42 професора, 19 је из Београда, четири из Ниша, три из Петровца на Млави, по два из Пирота и Кладова и по један из Аранђеловца, Јагодине, Ћићевца, Смедерева, Ваљева, Ужица, Лучана, Крушевца, Краљева, Горњег Милановца, Куршумлије и Бујановца. Дакле, анкетирани професори живе и раде у свим деловима Србије осим Војводине, како у великим, тако и у малим градовима и у селима. Само једна ос- 
новна школа из Војводине је у овом тренутку у систему школски DELF и професор те школе није се одазвао позиву да попуни анкету.

У првом делу анкете сакупили смо опште податке као што су име и презиме професора, школа у којој ради и град у којем се она налази, да ли се француски учи као први или други страни језик, који уџбеници се користе, колико професор у просеку има ученика у једном одељењу, колико одељења у једном разреду и колико укупно ученика у току једне школске године. Други део анкете посвећен је програму школски DELF: колико дуго је школа у систему школски DELF, колико дуго је професор испитивач за DELF испите, колико ученика се у просеку пријављује за полагање испита сваке године, који ниво ученици најчешће полажу у ком разреду, да ли су захтеви на испитима DELF у складу са програмима, да ли су уџбеници који се користе у складу са захтевима DELF испита, у којој мери професор успева да увежбава четири језичке вештине које одговарају појединим деловима испита DELF, да ли професор организује додатну наставу и колико часова у просеку за припрему ученика за испите као и којим вештинама посвећује највише пажње на часовима додатне наставе. У последњем делу анкете налазимо податке о односу ученика и родитеља према учењу француског језика и испитима DELF, према сазнањима професора: колико ученика који пријављују DELF испите учи француски језик и ван школе, како ученици који су пријавили испите DELF доживљавају полагање испита и стицање диплома DELF, какво је мишљење родитеља о полагању испита и стицању диплома као и какав је однос ученика према учењу француског језика након полагања испита.

Нажалост, нисмо били у могућности да испитамо све сегменте рада професора. Наиме, анкете са великим бројем питања, нарочито оних са отвореним одговорима, имају често малу излазност те њихови резултати нису поуздани. Стога смо одлучили да број питања сведемо на минимум неопходан за ово истраживање као и да буде што мање питања са отвореним одговорима, с тим што увек постоји могућност да се, по жељи, упише слободан коментар на крају анкете. Отворена питања поставили смо само за уписивање конкретних, врло прецизних података. У највећем броју случајева постављена су затворена питања са вишеструким избором одговора набрајања или 
интензитета (Ликертова скала). Мишљења смо да су умерена дужина анкете и врста питања допринеле солидној излазности од $60 \%$.

Од 42 анкетирана професора, 12 предаје француски као први страни језик (од чега 4 у основној школи „Владислав Рибникар“), а 31 као други страни језик (један професор ради у две школе). 20 професора има у просеку 25 ученика у једном одељењу, 11 професора има у просеку 20 ученика у одељењу, осам њих 15 ученика, а четири 30 ученика, док само 1 професор из једног малог града има у просеку 10 ученика у одељењу.

Серије уџбеника који се највише користи су Pixel (CLE International), чак 21 професор, затим следе Et toi ? (Clett), 12 профеcopa, Oh là là ! и Oh là là collège ! (CLE International), шест професора, све три серије како за први, тако и за други страни језик. Серију уџбеника Images de France (Завод за уџбенике и наставна средства) користе само три професора и то за први страни језик.

Искуство анкетираних професора као испитивача DELF врло је разнолико и креће се у распону од једне до 10 година. У односу на годину у којој је њихова школа ушла у систем школски DELF, 21 професор је стекао лиценцу испитивача исте године, 13 њих касније, а осам њих раније.

Више од 50\% анкетираних професора наводи да њихови ученици полажу ниво А1 најчешће у шестом и седмом разреду, нешто мање од $24 \%$ у осмом, а $19 \%$ већ у петом разреду (међу којима предњаче ученици основне школе „Владислав Рибникар“). Ниво А2 ученици полажу у $75 \%$ случајева у осмом разреду, нешто више од $35 \%$ њих у седмом и тек нешто више од 7\% у шестом, док ниво Б1 полажу искључиво у осмом разреду и то махом из основне школе „Владислав Рибникар“ и тек спорадично, по један кандидат из неке друге школе.

На питање да ли сматрају да су програми по којима се ради у основној школи у складу са захтевима на испитима DELF, 21 професор одговорио је „Углавном“, 16 ,делимично“, а само четири „врло мало“, односно један „сасвим“. Нешто је боља ситуација са мишљењем професора о томе да ли су уџбеници које користе у складу са захтевима на испитима DELF: 26 њих каже „углавном“, 11 „делимично“, троје „врло мало“, односно двоје „сасвим“, и то без обзира који уџбеник користе. 
Будући да се професори често жале да не успевају увек да обраде све што је програмом предвиђено због превеликог броја ученика у одељењу, због преобимног програма, незаинтересованости ученика итд, једно од питања било је „У којој мери успевате да радите четири језичке вештине које одговарају појединим деловима испита DELF ca свим ученицима, на редовним часовима? Искажите своју процену за сваку језичку вештину посебно, на скали од 1-10 (1 = веома мало, 10 = у потпуности). “Одговори на ово питање били су веома разноврсни и кретали су се углавном у распону од три до девет (са незнатним бројем одговора један, два и 10). И овога пута, никакво правило не постоји у смислу да професори који имају мање ученика у разреду, или који користе одређени уџбеник успевају више да раде неку језичку вештину и томе слично. Значајно је да је 19 професора, дакле чак $45,24 \%$, рад на разумевању писаног текста оценило бројем осам што значи да у великој мери успевају да развијају ту вештину на часу. За разумевање говора, на пример, тек 12 професора је дало оцену осам, за говор само шест а за писање само пет професора.

Сви професори наводе да организују додатну наставу за припремy за испите DELF намењену ученицима који су се пријавили за испит. Чак 26 њих организује више од 15 часова додатне наставе, 11 професора одржи у просеку између 10 и 15 часова, а остали око пет часова.

Поред додатне наставе коју организује професор у школи и која је бесплатна, неки ученици имају и приватне часове или уче језик у некој школи језика што свакако знатно утиче на њихов ниво знања и резултате на испитима. Само три професора из мањих средина поуздано знају да ниједан њихов ученик не учи француски језик ван школе, само пет њих каже да већина ученика учи језик и ван школе (међу којима махом професори основне школе „Владислав Рибникар“), 12 професора нема сазнања о томе док 16 професора сматра да мањи број њихових ученика има часове језика и ван школе.

Најзад, занимљиво питање, како нам се чини, било је „Којим вештинама посвећујете највише пажње на часовима додатне наставе? Обележите вештине бројевима од један до четири почев од оне којој посвећујете највише пажње.“ Чак 17 професора ставља разумевање говора на прво место, а само три на последње; 20 професора ставља 
разумевање писаног текста на последње место, а само 10 на прво; што се тиче писања, разлике нису тако велике: 11 професора га ставља на прво, а седам на последње место; коначно, када је у питању говор, 15 професора даје му предност и ставља га на прво место, а само пет на последње. Ни овога пута нисмо уочили никакве правилности у одговорима, дакле, они варирају без обзира на број ученика у одељењу, на уџбеник који се користи, на ниво који се полаже и сл.

Из свега овога могли бисмо закључити да резултати постигнути на испитима нису показатељи резултата рада са свим ученицима. С једне стране, број ученика који полажу испите у односу на број ученика који уче са њима у истом одељењу веома је мали изузев у основној школи „Владислав Рибникар“ где је заступљеност испита школски DELF далеко већа него у другим школама. C друге стране, ученици који су пријавили испит посебно се припремају на часовима додатне наставе где се посебна пажња посвећује најтежим захтевима на испиту.

Остаје, међутим, места за закључак да су ученици у стању да постигну изузетне резултате када се са њима ради на одговарајући начин, када их нема много у групи, када је доминантан индивидуализован приступ и, наравно, када су мотивисани и они и професори. У том смислу испити DELF јесу показатељ потенцијала ученика којима, морамо нагласити, ипак није потребно много да се развију: јасно постављен циљ општеприхваћен (од стране ученика и професора), двадесетак додатних часова на годишњем нивоу, мало више рада прилагођеног њиховим јаким и слабим тачкама, мало групног рада за постизање заједничког циља и лична мотивација.

Последњи део анкете бави се перцепцијом DELF испита од стране ученика кандидата и родитеља: како доживљавају додатни рад и напоре које улажу како ученици тако и професори, резултате испита, стицање дипломе, и да ли то утиче на мотивацију и даљи рад ученика.

На питање „Какав је однос ваших ученика који су пријавили испите према полагању испита и стицању диплома DELF? “ могуће је заокружити више одговора. Чак 34 професора одговара да су ученици мотивисани и да показују жељу да раде више да би положили испите, 29 њих истиче да су ученици поносни када стекну диплому француског Министарства просвете. Нешто мање од половине, само 20 про- 
фесора, констатује да су ученици задовољни оценама које добијају на испитима. Ово последње је занимљив показатељ схватања појма добре оцене у нашим условима школовања: добри и вредни ученици у Србији (и не само они) добром оценом сматрају само петицу па су неретко разочарани оценом на испиту. Наиме, највиша оцена на испиту је 100 што се, наравно, изузетно ретко добија и оцене као што су 80 или 90/100, које су изузетно добре, у очима многих ученика нису виђене као такве. С друге стране, ниједан професор није заокружио понуђени одговор да ученици нису задовољни оценама које добијају на испитима. Најзад, само један професор наводи да ученици сматрају испите обавезом и додатним оптерећењем, али да их полажу због оцене у школи.

Што се тиче односа родитеља према полагању испита и стицању диплома, 33 професора наводи да родитељи сматрају да је то веома добро и охрабрују своју децу да полажу испите. Професори такође истичу да су родитељи задовољни што деца знање стичу у школи, а не ван ње, и што не морају да путују у Београд, Ниш, Нови Сад или Кладово, већ имају могућност да полажу испите у свом граду. Једна професорка из једног мањег места чак примећује појачано интересовање за њену школу, управо захваљујући томе што је акредитована за програм школски DELF те се у школу уписују и ученици који јој територијално не припадају.

Последње питање у анкети тиче се односа ученика према учењу француског језика након полагања испита и стицања дипломе. По речима 28 професора ученици су мотивисани и уче са још већим жаром, док девет њих примећују да ученици не мењају ништа у свом односу према учењу.

Интересатно је запажање неколицине професора да су ученици више заинтересовани за DELF испите у нижем узрасту и да стога има много кандидата у шестом разреду и нешто мање у седмом, а да потом интересовање слаби па их у осмом разреду има знатно мање.

Из овог прегледа одговора на питања од значаја за нашу тему може се закључити да припремање и полагање DELF испита има позитиван утицај на однос ученика према учењу француског језика и да се појављује као фактор мотивације и извор добрих, лепих осећања која имају изузетно важно место у процесу учења, баш као и мотивација. 


\section{Неки аспекти начина рада професора испитивача за DELF испите}

Током више од две деценије постојања DELF испита у Србији, у почетку само у својству испитивача, од 2002. године као потпредседник националне комисије за испите DELF/DALF, а од 2005. године и као инструктор испитивача, имали смо прилике да разговарамо са многим професорима испитивачима о утицају DELF испита како на ученике тако и на њих саме и на њихов рад. Сталан пораст броја ученика који стичу дипломе, пролазност на испитима која некада достиже и 99\% и број акредитованих школа у програму школски DELF који се стално повећава показују у којој мери су испити DELF занимљиви и значајни за младе у Србији који уче француски језик. Осим званичних резултата у смислу оцена и диплома, треба истаћи и неформалне резултате, можда мање видљиве али не и мање драгоцене. С једне стране, професори су, баш као и њихови ученици, срећни и поносни на резултате што има великог утицаја на њигову мотивацију која je кључни фактор успеха. C друге стране, DELF подстиче напоре професора да унапређују свој свакодневни рад. Да би постигли жељене резултате, професори морају да поставе другачије циљеве, да промене свој начин рада, да усвоје нове критеријуме евалуације, да дају приоритет индивидуализованом приступу у настави и да прилагоде свој рад реалним потребама својих ученика.

Поставља се питање откуд толика ефикасност DELF испита, због чега су они толико важни. Знамо да у процесу учења језика има много чинилаца од којих су неки неопходни, а неки пожељни, али сви они имају своје место у формирању знања и компетенција ученика. Верујемо да су, када је у питању школски DELF сви неопходни чиниоци присутни и могли бисмо их дефинисати на следећи начин:

- Сви актери образовања су укључени (Министарство просвете, школе, професори, ученици, родитељи);

- Способности ученика и професора су признате, награђене и дипломом која долази као спољна евалуација, а не само оценом стеченом у школи;

- Мотивација ученика утиче позитивно на мотивацију професора и обрнуто; 
- Постоји јасно дефинисан циљ којем се тежи и за чије остварење се прави одабир најбољих стратегија;

- Професори испитивачи имају обуку која је веома добро конципирана, припремљена и изведена.

Задржаћемо се на кратко на овом последњем чиниоцу, на обуци испитивача која се изводи у четири фазе. Прва је анализа потреба и осмишљавање семинара, односно прилагођавање постојећег плана и материјала за обуку које обезбеђује CIEP конкретним потребама професора који ће похађати обуку. Друга фаза су сами семинари in situ, трећа фаза је самосталан рад професора и четврта, посматрање испита уз сталан менторски рад инструктора. Следи припремање ученика за полагање испита и на крају учешће испитивача у раду жирија током испита, све то уз пратњу и помоћ инструктора и других, искусних испитивача. Од првог дана обуке in situ и током самосталног рада, професори су у сталном контакту са инструкторима путем мејла, а peђе и телефоном. И након стицања звања испитивача DELF, приликом припремања ученика за испите, током испита као и приликом прегледања и оцењивања радова, тај контакт је редован и, по речима самих професора, за њих врло значајан. Размена мишљења о проблемима са којима се сусрећу и недоумицама и тешкоћама у току припрема не само да је својеврстан продужетак обуке, већ истовремено представља и добар материјал за неформалну евалуацију обуке, како од стране професора, тако и од стране инструктора. Како подвлаче Галисон и Пирен (1999):

Право усавршавање је само оно у којем професор поново концептуализује и теоретише концепте и теорије за себе самог. [...] То омогућава професорима да теоретишу сами полазећи од свог личног искуства, али и да примењују већ постојеће теоризације у својој пракси и на њу. ${ }^{4}$ (Галисон и Пирен 1999, 41)

Кроз то стално окретање теорији и повезивање теорије и праксе формира се нови професионални идентитет професора. Није ту реч о новој компетенцији коју треба придодати компетенцијама које профе-

4 Све цитате превео је аутор чланка. 
сор већ има, већ о новом професионалном идентитету који уводи нову праксу и постиже нове резултате.

Веома важну улогу у подстицању на промишљање и преиспитивање има ЗЕРОЈ са којим се већина професора први пут сусреће на DELF семинарима. O том делу је много већ речено и написано. Ми ћемо овом приликом само подвући да је један од два основна циља изложена већ на самом почетку ЗЕРОЈ којима су се руководили његови аутори управо

подстицати све актере у области живих језика, укључујући и оне који их уче, да постављају себи питања као што су: [...] Који облик учења је потребан када покушавамо да користимо неки нови језик? Како одређујемо своје циљеве и дефинишемо напредак од потпуног незнања до ефективног овладавања страним језиком? Како се одвија учење језика? Како помоћи људима да боље науче неки језик? (ЗЕРОЈ 2005, 4)

Друга кључна тачка јесте, како нам се чини, увођење појма актера, односно употребе језика. Како наглашава Бургињон, „у фокусу више није оно што је научено, већ употреба онога што је научено. То је значење израза 'учење-употреба језика'. Треба прећи са логике учења на логику употребе“ (2011a, 3). Смисао учења језика није стицање декларативних знања, већ развијање способности употребе тих знања у циљу комуницирања и делања.

Још једну врсту подстицаја на преиспитивање пружају сасвим другачија концепција и функција оцењивања, односно евалуације рада и постигнутог напретка ученика које професори великом већином први пут срећу на семинарима DELF. Обично је њихова пракса по питању оцењивања сасвим другачија, своди се често на оцењивање познавања граматике и углавном одражава начин рада професора који инсистирају на подучавању, односно учењу граматике. На испитима DELF евалуирају се четири компетенције у комуникацији, а познавање граматике и лексике није само себи сврха већ има своју улогу као неопходно оруђе, неопходан алат за комуникацију. Реч је о евалуацији, а не о једноставном оцењивању, а та евалуација је увек позитивна и критеријумска, онаква какву заговара 3ЕРОЈ.

За Бургињон $(20116,6)$, евалуација језичких компетенција је пре свега „промена парадигме“, замена парадигме знања парадигмом 
компетенције, замена квантитативног начина оцењивања (оцена) квалитативним (критеријуми, показатељи достигнућа). У истом смислу Таглијант $(2005,10)$ прави разлику између сумативне и нормативне евалуације с једне стране и формативне и критеријумске евалуације и ауто-евалуације с друге стране, између норме и критеријума, између оцене и информације са коментарима.

Управо томе се професори уче на обуци за DELF испитиваче и за припремање ученика за испите. Откривајући ЗЕРОЈ или продубљујући своје познавање његових основних поставки и упознајући се са принципима позитивне евалуације и форматом испита DELF, професори изграђују основу за другачију праксу у коју су уткани и нови циљеви, нов смисао како подучавања и учења тако и евалуације, па самим тим и нов начин рада и нове стратегије. Наиме, није могуће посматрати евалуацију кроз другачију призму без промишљања и кориговања или знатног прилагођавања свог свакодневног рада и својих педагошких, дидактичких и методичких навика и уверења тој новој тачци гледишта. Ако имамо у виду правило да евалуација треба да изгледа онако како изгледа рад на часу, како у погледу садржаја, односно онога што се евалуира, тако и у погледу форме, односно начина на који се евалуира, јасно је да промене у процесу евалуације морају повлачити и промене у процесу подучавање/учење. Професори који познају ово правило, а инструктори током обуке на њему стално инсистирају, не могу да наставе рад као пре обуке. Промене се саме по себи намећу мада се, морамо нагласити, не могу десити преко ноћи нити одвијати без потешкоћа.

Обучавајући професоре како да припремају своје ученике за испите DELF и како да испитују кандидате, увели смо „на мала врата“ читаву лепезу поступака и активности, промишљање и преиспитивање, који су у складу са комуникативним приступом и акционом перспективом у учењу страних језика. Наведимо овде само неке од њих: рад на пројектима и задацима, развијање језичких вештина, диференцијација и индивидуализација процеса подучавање/ учење, позитивна и критеријумска евалуација, граматика као неопходно средство за комуникацију, а не као као крајњи циљ итд.

И сами професори испитивачи сведоче о томе у неформалним разговорима и разменама путем мејла које водимо док припремају 
своје ученике за испите, или се и сами припремају за рад у жирију, или пак исправљају писане задатке. Са неколицином њих водили смо

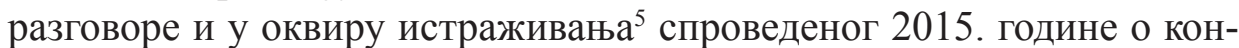
тинуираном усавршавању професора француског језика у Србији у којем значајно место заузима и обука за DELF испитиваче. Сви професори, без изузетка, подвлаче да су битно променили начин рада на редовним часовима, са свим ученицима у одељењу, од када су постали DELF испитивачи.

\section{Закључак}

Из свега горе реченог намеће се закључак да, несумњиво, школски DELF доприноси како постигнућима ученика и угледу школе и професора, тако и мотивацији ученика и професора. Осим мотивације, код ученика се развијају и трајна позитивна осећања која их и у старијем узрасту везују за француски језик и културу. На тај начин, школски DELF доприноси индиректно и популаризацији француског језика у Србији уопште и, ако не баш повећању, бар одржавању или у најмању руку успоравању смањења броја ученика који бирају француски језик у основним школама.

Ова добробит не ограничава се, наравно, само на основне школе, она је присутна и добро приметна и у средњим школама, али нама се чини да је тај утицај од пресудног значаја управо код деце нижег узраста зато што се тада опредељују за неки страни језик, али и зато што се на тај начин доприноси фиделизацији како ученика, тако и родитеља.

Не смемо заборавити ни стручно усавршавање професора испитивача код којих је, како смо констатовали, примећен знатан помак у поимању сврхе учења страних језика уопште и улоге професора у процесу подучавање/ учење па самим тим и у њиховој пракси. Нова знања стечена током обуке у свим њеним видовима (ограничене у времену и трајне, формалне и неформалне...) не остају „похрањена у некој фиоци“ већ се примењују зарад остваривања конкретног циља

5 Истраживање је спроведено током пролећа 2015. године за потребе мастер рада на Универзитету Стендал Гренобл-3, на тему континуираног усавршавања професора француског језика у Србији. 
са јасно дефинисаним роковима и мерљивим резултатима, циља који је заједнички ученицима и професорима. Управо та педагошка и методичка димензија коју су професори усвојили и која је заживела у њиховом раду представља, по нашем мишљењу, највећи успех пројекта DELF, а нарочито пројекта школски DELF у Србији.

\section{Библиографија}

Бургињон 2011a: Claire Bourguignon. « L'enseignement des langues et le CECRL : d'une logique de contenu à une logique de projet. »Consulté en mars 2017. http://www.cndp.fr/crdp-dijon/IMG/pdf/Bourguignon_ logique_projet_ens_langues_2011.pdf.

Бургињон 2011б: Claire Bourguignon. « Evaluer la compétence en langue : C'est quoi ? C'est pourquoi ? C'est comment?» Consulté en août 2015. http://www.ac-grenoble.fr/disciplines/interlangues/file/Aconsulter/ Claire_Bourguignon/Bourguignon_Claire_Eval_Comp.pdf

Галисон и Пирен 1999: Robert Galisson, Christian Puren. La formation en question. Paris : CLE international.

Савет Европе 2005: Conseil de l'Europe. Cadre européen commun de référence pour les langues. Apprendre, enseigner, évaluer. Paris : Didier.

Таглијант 2005: Christine Tagliante. L'évaluation et le Cadre européen commun. Paris : CLE international. 


\title{
Anastazija Jadrijev-Došenović
}

\section{DELF SCOLAIRE EN SERBIE : RESULTATS DES EXAMENS ET L'ENSEIGNEMENT/APPRENTISSAGE A L'ECOLE}

\begin{abstract}
Résumé
Les examens DELF/DALF permettant l'obtention des diplômes du ministère de l'Education nationale de France sont organisés en Serbie depuis 1994. En 2007 les premières écoles ouvrent leurs portes au programme DELF scolaire (niveaux A1-B2) organisé dans des établissements scolaires pour les élèves du deuxième cycle de l'école primaire (correspondant au collège en France) et des écoles secondaires.

L'auteure présente l'introduction du DELF scolaire en Serbie ainsi que les résultats des examens. En plus d'une analyse quantitative, l'auteure donne une analyse des relations de cause et de conséquences visibles, possibles et/ou attendues entre le processus d'enseignement/apprentissage d'un côté et la passation des examens DELF scolaire de l'autre. Deux questions importantes s'imposent. La première concerne les possibilités réelles et l'efficacité de la pratique actuelle dans le processus d'enseignement/apprentissage dans les conditions caractéristiques des établissements scolaires en Serbie : estce que cette forme d'évaluation externe des compétences communicatives d'apprenants traduit les résultats de leur travail pendant les cours à l'école. La deuxième question concerne plutôt les enseignants : la formation DELF pour examinateurs-correcteurs suivie par les enseignants et la préparation des élèves à la passation des examens, entraînentelles une modification des pratiques des enseignants (priorités, choix d'approches dans le processus d'enseignement/apprentissage, autonomisation des apprenants, évaluation...)
\end{abstract}

Mots clés : écoles primaires, DELF scolaire, enseignement de la langue française dans les écoles du système. 